\title{
Contoured Vertical Distribution and Spatio-temporal Variation of an Intertidal Macroalgal Assemblage in King George Island, Antarctica
}

\section{Young Wook Ko}

Korea Polar Research Institute

\section{Dong Seok Lee}

Sungkyunkwan University

\section{Sanghee Kim}

Korea Polar Research Institute

Jeong Ha Kim

Sungkyunkwan University

Han-Gu Choi ( $\square$ hchoi82@kopri.re.kr)

Korea Polar Research Institute

\section{Research Article}

Keywords: Antarctica, Contour plot, Intertidal zone, Macroalgae, Short-term variability

Posted Date: June 24th, 2021

DOl: https://doi.org/10.21203/rs.3.rs-627145/v1

License: (c) (1) This work is licensed under a Creative Commons Attribution 4.0 International License. Read Full License 


\section{Abstract}

Short-term variability, spatial variability, and the vertical distribution of an intertidal macroalgal assemblage were examined on the coast of Barton Peninsula, Maxwell Bay, King George Island, Antarctica. Sampling was performed during the three austral summer seasons from November 2016 to January 2019. The sampling interval for short-term variability was 1-2 months. Sampling for spatial variability was performed at two sites $400 \mathrm{~m}$ apart. Eighteen algal species were identified, with 75\% relative coverage of the predominant red Iridaea cordata and endemic brown Phaeurus antarcticus. Summer abundance can be described as a shift from I. cordata to $P$. antarcticus, and the change in color is intuitively presented using a contour plot for the first time. Short-term variation in the macroalgal assemblage showed $78.35 \%$ similarity between one month and $64.61 \%$ similarity between two months. The spatial variation analysis indicated $77.13 \%$ similarity between the assemblage at the two sites. If global warming continues, the algal population of this region is expected to expand. P. antarcticus, which is primarily found in the subtidal zone, is predicted to relocate southward or higher in the near future. Long-term monitoring of this research region, which is dominated by the two species, is warranted to determine the impact of global warming on the macroalgal assemblage.

\section{Introduction}

Macroalgae are important direct food sources in many countries and primary producers in the world's oceans. Macroalgae, which have the structural complexity of a thallus and holdfast, serve as shelters from external waves and ultraviolet (UV) light, refuges for protection from predators, and nurseries for animals and their juveniles. In Antarctica, macroalgae perform the same general ecological functions ${ }^{1-6}$. A total of 130 macroalgae species have been reported in Antarctica, with the majority occurring in the western Antarctic Peninsula 6-8; this value represents a low species richness, even when compared to southern Australia where almost 1,500 macroalgae have been reported ${ }^{9}$. However, due to insufficient scientific collection and difficulty in accessibility and logistics, the diversity of macroalgae in Antarctica has likely been underestimated ${ }^{10}$. Endemic Antarctic macroalgae account for $27.1 \%$ of all species, owing to isolation by the Antarctic Circumpolar Current. Kelps (order Laminariales), which are brown algae; thrive in shallow waters around the world except for in Antarctica. In Antarctica, Desmaretiales and Ascoseirales (an endemic kelp-like brown algal order) play a critical role in performing the ecological functions typically performed by kelp ${ }^{11}$. In East Antarctica where the latitude is high, the taxonomic diversity of seaweeds is very low due to the limited availability of light and extremely harsh environment, although a few species do exist such as Palmaria decipiens, Phyllophora antarctica, and Iridaea cordata 12-14.

Antarctica, which is isolated from the other continents, is known for its extremely harsh climates. In the context of macroalgae habitats, the ice, light, and temperature conditions of Antarctica are very poor compared to those of temperate and tropical regions ${ }^{2,6}$. Ice is a major environmental factor and has a great influence on all benthic organisms, including macroalgae, in Antarctica. Specifically, thick sea ice 
limits the light conditions and affects the growth of macroalgae, and icebergs derived from glaciers result in direct disturbance through scouring ${ }^{15}$. This scouring action limits macroalgae inhabitation to less than $15 \mathrm{~m}$ depth, with a few exceptions up to $25 \mathrm{~m}$ depth ${ }^{16,17}$. Fast ice, on the other hand, can be "locked in" icebergs and reduce seabed disruption ${ }^{18}$. In intertidal zones, brash ice or growlers, which are floating ice with a diameter less than $1 \mathrm{~m}$, often cause a trampling effect ${ }^{19}$. In addition, day length influences the seasonal development of macroalgae. In King George Island, the duration of daylight varies from 5 to 20 hours throughout the year; as the day length increases after winter, the development of season anticipators (mostly endemic species), such as Phaeurus antarcticus, Ascoseira mirabillis, and Desmarestia antarctica, is induced $6,20,21$. The average coastal water temperature for the entire Antarctic continent is below $0^{\circ} \mathrm{C}$ throughout the year, whereas the east coastal temperature of the Antarctic Peninsula, Victoria Land, Adelie Coast, Wilkes Land, Queen Mary Coast, Mac Robertson Coast, and Enderby Land is below $-1.8^{\circ} \mathrm{C}$ throughout the year. Because of the frozen conditions, it is difficult for benthic macroalgae to exist ${ }^{12-14}$. However, the coastal water temperature of the South Shetland Islands, located at the tip of the Antarctic Peninsula, ranges from -1.8 to $2.0^{\circ} \mathrm{C}$, which allows macroalgae to actively grow along the coast of the western Antarctic Peninsula during the summer ${ }^{22}$.

The intertidal zone is among the most studied marine habitats worldwide and its ecosystem has been well described ${ }^{23}$. In Antarctica, the intertidal zone has low taxonomic diversity relative to the subtidal zone due to the severe influence of ice disturbance. As a result, despite the easier accessibility, there have been few research studies of the intertidal zone in this region ${ }^{10}$. The ice foot and growlers are the principal causes of ice disruption in the intertidal zone. The ice foot develops in winter, covering some areas of the intertidal zone and affecting benthic organisms, while the growlers trample benthic species. As a result, macroalgae can only grow in places where the influence of the ice foot is low, and colonization by macroalgal associated zoobenthos becomes possible in these areas ${ }^{24,25}$. Previous research on the macroalgae of the Antarctic intertidal zone includes taxonomical descriptions and vertical zonation studies, as well as studies on the structure of the assemblage and interactions with the environment or organisms ${ }^{25-29}$. The majority of studies have been conducted on King George Island, South Shetland Islands, with recent examples including studies on scale-dependent spatial variation and temporal variation 27,28 .

We attempted to conduct research on spatio-temporal variation of different scales at different sites. The aims of this study are as follows. First, we intended to newly express the vertical distribution of the macroalgal assemblage of the Antarctic intertidal zone in a continuous manner using a contour plot, rather than the conventional discontinuous descriptions of the upper, middle, and lower levels. Second, we wanted to determine how much temporal variation in the macroalgal assemblage occurs over one or two months during the austral summer, as well as determine what species drive this variation and to what extent. Third, we wanted to investigate the extent of spatial variation at the local scale (i.e., 100s of meters) and to assess the spatial diversity of the intertidal zone in Maxwell Bay using reported data. 


\section{Materials And Methods}

\section{Study site}

This study was carried out on an intertidal rocky platform on the southern shore of Barton Peninsula $\left(62^{\circ}\right.$ $15^{\prime}$ S, $58^{\circ} 44^{\prime} \mathrm{W}$ ), about $3.5 \mathrm{~km}$ away from King Sejong Station (KSS; Fig. 3). The intertidal platform is composed of volcanic rocks formed during the Eocene Epoch ${ }^{56}$, measures approximately $1 \mathrm{~km}$ long and $100 \mathrm{~m}$ wide, and is connected to the igneous cliffs of the land. From the spray zone to the high tide zone, the beach consists of typical pebbles and coarse sand. At the mid and lower tide zones, it is composed of rocky beds scattered with cobbles (Fig. 4). The tidal regime is mixed-semidiurnal and the maximal tidal range (Highest/Lowest Astronomical Tide; HAT-LAT) is $185 \mathrm{~cm}$ in Admiralty Bay, King George Island (www.tide-forecast.com/locations/Admiralty-Bay-South-Shetlands/tides/latest). For the tide forecast on Barton Peninsula at KSS, data from nearby Admiralty Bay are used. During extreme low tide, only two or three days each month are appropriate for conducting a survey of the intertidal zone and the maximum sampling time is only about two hours.

The climatological normal temperature observed in $\mathrm{KSS}$ is $-1.7^{\circ} \mathrm{C}$, the predominant wind direction is northwest, and the average wind speed is $8.0 \mathrm{~m} / \mathrm{s}$ (data from Korea Polar Data Center; http://kpdc.kopri.re.kr). Sea ice formation in Maxwell Bay, where Barton Peninsula is located, generally occurs between late July and mid-September of the austral winter, although it does not happen every year. For example, sea ice freezing was observed in 2016 and 2017, but there was no freezing in 2018 or 2019.

\section{Sampling}

Surveys of temporal-spatial variation in the macroalgal assemblage were performed at sites $A$ and $B$ from November 2016 to January 2019. Sampling was performed with a one-month time difference (December 2018 and January 2019) and again with a two-month time difference (November 2016 and January 2017) to analyze short-term changes in the macroalgal assemblage during the austral summer at site A (Table 4). In January 2018, sampling was conducted at sites A and B (approx. $400 \mathrm{~m}$ apart) to analyze spatial variation in the macroalgal assemblage. The time gap of sampling between the two sites was two days. To collect data for the vertical distribution of the macroalgal assemblage, vertical lines were installed at each site. Two quadrats $(50 \mathrm{~cm} \times 50 \mathrm{~cm}$ ) were placed on the left and right sides of the vertical line at $5 \mathrm{~m}$ intervals ( $10 \mathrm{~m}$ intervals for the first survey) and photographs were taken. Nondestructive sampling was performed to minimize damage to the Antarctic intertidal macroalgal assemblage and small amounts of the samples were collected for macroalgal identification. An Olympus Stylus TG-4 Tough (TG-4; Olympus Imaging Corporation, Japan) and DSC-RX100M5A (Sony Corporation, Japan) cameras were used to photograph the plots in this study. Species identification and percent cover in each quadrat were performed through visual estimation on a monitor. The length of the vertical lines varied due to different low water spring heights at each sampling time. In the case of site A, the basic 
vertical line was set to the mid-point $60 \mathrm{~m}$ away from the start-point, and the vertical line was extended to the lower intertidal zone as much as possible at each survey time. Macroalgae were identified according to available taxonomy in AlgaeBase ${ }^{57}$ at the lowest possible taxonomic level, with the exception of crustose coralline algae (CCA) which were classified at the subfamily level.

\section{Macroalgal assemblage characterization and analysis}

We analyzed the short-term change in the macroalgal assemblage over one or two months by pooling quadrat data and a list representing the mean percent cover of each species at each sampling interval. Based on these data, the macroalgal assemblage was characterized using ecological indices such as richness, diversity, and evenness. Richness $(S)$ indicates the total number of species observed during the survey time. Diversity were calculated using the Shannon-Wiener diversity index $\left(H^{\prime}=\sum\left(\mathrm{p}_{\mathrm{i}} \times \log _{e} p_{\mathrm{i}}\right)\right)$, and $p_{i}$ is the relative abundance of taxon $i$. Evenness were evaluated the Pileous index $\left(J^{\prime}=H^{\prime} / \log S\right)$. CLUSTER analysis was performed to calculate the temporal change in the macroalgal assemblage between the sampling intervals. Similarity of percentage (SIMPER) analysis ${ }^{58}$ was performed to confirm the contribution of each species to the temporal change. In order to estimate the similarity of the macroalgal assemblage across sampling seasons and intervals (1 month earlier/later; 2018-19 season, 2 months earlier/later; 2016-17 season), a resemblance matrix was created by calculating the BrayCurtis similarity. Prior to the SIMPER and resemblance matrix analyses, all data were subjected to a pretreatment procedure involving standardization and square root transformation ${ }^{58}$. In addition, the spatial variation of the macroalgal assemblage surveyed in the 2017-18 season was compared at two different

sites (site $A$ and $B$ ). Characterization of the macroalgal assemblage for the spatial variation analysis and the statistical analysis of communities was conducted in the same manner as described above.

\section{Contour plotting for vertical distribution}

In order to visualize the temporal change in the vertical distribution of macroalgae in the intertidal zone, contour plots were created using Surfer 9 (Golden Software, Inc.). Four contour plots $(2$ seasons $\times 2$ times) were generated using the algal coverage data. Each contour plot was created by overlapping the five contour plots generated by the total algal cover and five major species (Iridaea cordata, Phaeurus antarcticus, Palmaria decipiens, Desmarestia anceps, and CCA) data. The vertical distribution of the total algal cover was represented by a line, while the major five species were represented by distinct patterns and color gradients. The Kriging technique was used for the gridding method, which consisted of 700 grids ( 100 rows $\times 7$ columns), to generate the contours. The contour plots represent the sampled area ( $1 \times$ $70 \mathrm{~m}$ ) on a vertical line; for better visualization, an $8 \times$ scale was applied for the $x$-axis $(8 \times 70$ plot scale length). Although contour plots are mainly used to express elevation in geology and geography, in oceanography they have been used for intuitive analysis of the distribution of chemical variables in the 
water column. To the best of our knowledge, this is the first attempt to express macroalgal abundance using contour plots.

\section{Species composition and spatial structure of Maxwell Bay using previously reported data}

To expand the spatial variability of the macroalgal assemblage, data from previous studies around Maxwell Bay in King George Island were extracted. The data were rearranged and pooled by site, and CLUSTER analysis was then performed based on our results. Data from 9 sites and 11 were reported in

four studies ${ }^{26-28,37}$. The major and minor species were classified based on the criterion of coverage of $5 \%$ among the species, and the relative coverage was calculated by the point or site. A pie chart was then created on the map. For spatial variability among sites, a dendrogram was created through CLUSTER analysis and the structure in the data was tested and grouped through similarity profile routine (SIMPROF) analysis ${ }^{58}$. Data processing (pre-treatment and resemblance) was performed in the same manner described above. The SIMPER, CLUSTER, and SIMPROF analyses, as well as the ecological index, used in this study were performed using PRIMER 6 software (PRIMER-E, Ltd., UK).

\section{Results}

\section{Short-term variation in the macroalgal assemblage and contour plotting of the vertical distribution}

The similarity of the macroalgal assemblage surveyed with a one-month difference (December 2018 and January 2019) was 78.35\%, while that surveyed with a two-month difference (November 2016 and January 2017 ) was $64.61 \%$. The similarity between the sampling seasons for the December assemblage was $64.48 \%$, indicating inter-year variation. The similarity between the sampling seasons was $65.98 \%$ (Table 1). A total of 15 species were identified at site A during the two austral summers. Thirteen and 12 species appeared in the 2016-17 and 2018-19 seasons, respectively (Table 2). Iridaea cordata and Phaeurus antarcticus are abundant species that characterize the intertidal zone of the Barton Peninsula. Iridaea cordata was the most abundant species in 3 of the 4 samplings and showed a percent cover of $34.96 \%$ in November 2016. The relative coverage (RC) of these species reached 73.2\% (Supplementary Table 1). Phaeurus antarcticus was the second most abundant species; however, in January 2017 it showed the highest percent cover at $41.38 \%$ and the RC reached $62.3 \%$. The total macroalgal coverage increased 1.19 times from $69.36 \%$ to $82.75 \%$ in one-month interval and 1.39 times from $47.79 \%$ to $66.38 \%$ in a two-month interval.

The species richness $(S)$ by sampling time showed no clear trend, ranging from 7-13 species. The Shannon-Wiener diversity $\left(H^{\prime}\right)$ and Pileous evenness index $\left(J^{\prime}\right)$ showed a larger macroalgal assemblage in January within the same sampling season. The diversity values were low, with a range of $0.979-1.753$ (Table 2). In the 2018-19 season, the change was relatively conspicuous from 1.381 to 1.753 for one month, but not in the 2016-17 season. The evenness value increased from 0.600 to 0.731 for one month in the 2018-19 season and from 0.382 to 0.555 for two months in the 2016-17 season. This variation in 
diversity and evenness suggests inter-year variation, reflecting a decrease in the extreme abundance of $I$. cordata within the macroalgal assemblage. The RC of $l$. cordata decreased from $49.1 \%$ to $30.9 \%$ in the 2018-19 season and from $73.2 \%$ to $28.2 \%$ in the $2016-17$ season (Supplementary Table 1 ).

Furthermore, the RC of Phaeurus antarcticus remarkably increased from $11.4 \%$ to $62.3 \%$ in the $2016-17$ season, affecting the fluctuations in diversity and evenness (Supplementary Table 1).

The dissimilarity of the macroalgal assemblage for the one-month sampling interval was $21.65 \%$ and $35.39 \%$ for the two-month sampling interval (Table 2). In the 2018-19 season, the species that made the highest contribution to dissimilarity was Desmarestia anceps (23.64\%), whose cover increased significantly from $0.93 \%$ to $9.75 \%$ for one month. The species that contributed more than $5 \%$ to dissimilarity were Desmarestia antarctica, I. cordata, Desmarestia menziesii, Phaeurus antarcticus, Monostroma hariotii, and CCA, in increasing order of contribution. In the 2016-17 season, the species that made the highest contribution to dissimilarity (31.32\%) was $P$. antarcticus, and its cover increased significantly from $5.43 \%$ to $41.38 \%$ for two months. The species that contributed more than $5 \%$ to dissimilarity were I. cordata, CCA, Ascoseira mirabilis, and Adenocystis utricularis, in increasing order of contribution. According to the SIMPER results, the increase or decrease of the two predominant species (i.e., I. cordata and P. antarcticus) during the austral summer in the survey area contributed to the change in macroalgal assemblage structure. The contributions of these two predominant species accounted for $19.19 \%$ and $53.78 \%$ in the $2018-19$ season and $2016-17$ season, respectively. Desmarestia anceps and Desmarestia menziesii, which made a high value contribution in the 2018-19 season, either made a low value contribution or did not appear in the 2016-17 season. The contribution of CCA to the change in macroalgal assemblage structure was $5.35 \%$ and $12.42 \%$ in the $2018-19$ and $2016-17$ seasons, respectively. We did not obtain accurate coverage of CCA encrusting the rock substrate because sampling was performed without consideration of the understory. Therefore, the contribution of CCA was underestimated due to the influence of overstory predominant species

The vertical distribution of macroalgae shown by the contour plots is as follows (Fig. 1). First, inter-year variation appeared in the dominance of total algal cover and the major species. According to the contour plots in January, the total cover did not exceed $30 \%$ up to about the $30 \mathrm{~m}$ point in 2017; however, in 2019, due to the dominance of $I$. cordata and presence of Palmaria decipiens, the total cover was high. The vertical distribution and dominance of I. cordata and Phaeurus antarcticus were distinctly different even after the $30 \mathrm{~m}$ point. For the short-term sampling interval, the abundance of the major species was slightly changed. In the 2018-19 season, I. cordata decreased during the one-month interval, while the abundance of $P$. antarcticus and Desmarestia anceps increased. In the 2016-17 season, I. cordata decreased and $P$. antarcticus significantly increased overgrowing on CCA at the $30 \mathrm{~m}$ point for the twomonth interval.

\section{Spatial variation of macroalgal assemblage}

For the spatial variation analysis of the intertidal zone of Barton Peninsula, a total of 14 species appeared at sites $A$ and $B$, which were approximately $400 \mathrm{~m}$ apart. The similarity of the assemblage 
between the sites was $77.13 \%$ (Table 3). The total algal coverage was $56.15 \%$ and $53.64 \%$ at site $A$ and site $B$, respectively, indicating little difference. The richness of site $B$, where 13 species appeared, was slightly higher than that of site A, where 11 species appeared. The diversity values of site $A$ and site $B$ were 1.44 and 1.53 , respectively, indicating higher diversity at site B than site A. Evenness showed little difference between the two sites. For the predominant species I. cordata and Phaeurus antarcticus, the $\mathrm{RC}$ of the total algal cover was $75.1 \%$ and $64.1 \%$ at site $A$ and site $B$, respectively, and the dominance of site A was higher than that of site B. According to the SIMPER analysis, Palmaria decipiens, Desmarestia anceps, Desmarestia menziesii, CCA, and $P$. antarcticus contributed about $70 \%$ to the dissimilarity of the two macroalgal assemblages. In particular, the coverages of $P$. decipiens and $D$. anceps, which have the highest SIMPER contribution, were 5.18 and $1.00 \%$ at site $A$ and $6.95 \%$ and $0.19 \%$ at site $B$, showing contradictory between the two sites

\section{Discussion}

\section{Temporal variation and contoured vertical distribution}

In the present study, we use contour plots to present the vertical distribution of the major species of the macroalgal assemblage along the southern coast of the Barton Peninsula, King George Island, Antarctica (Fig. 1). In this way, we provide an intuitive visualization of the upper to lower levels of the intertidal zone. In previous studies of King George Island, the intertidal zone was classified into high, middle, and low levels and macroalgal assemblage data were provided for each tidal zone ${ }^{26-28}$. This method results in discontinuous information about the vertical distribution. Using the macroalgal distribution by tidal level reported in previous studies, zonation in the $20-30 \mathrm{~m}$ zone, and dominance of $I$. cordata and Phaeurus antarcticus below $30 \mathrm{~m}$, we defined the middle level as up to $30 \mathrm{~m}$ and the low level as below $30 \mathrm{~m}$. In the intertidal zone of the Potter Peninsula, which is $3 \mathrm{~km}$ east of our study site, Pyropia endiviifolium is prevalent in the high level; I. cordata, Palmaria decipiens, and Adenocystis utricularis are prevalent in the middle level; and I. cordata and $P$. antarcticus are prevalent in the low level, with a total macroalgal cover of $21.28 \%, 50.89 \%$, and $68.70 \%$ in the high, middle, and low tidal levels, respectively ${ }^{27}$. According to Kim

${ }^{26}$, who studied a site $1.5 \mathrm{~km}$ west-northwest of our study area, Monostroma hariotii, A. utricularis, I. cordata, and $P$. decipiens appeared between the middle and low levels, while Desmarestia antarcticus, Curdiea racovitzae, Ascoseira mirabillis, P. antarcticus, and CCA appeared in the low level. As mentioned above, the distribution of algae in the intertidal zone may be counteracted by the tidal level of King George Island; based on $30 \mathrm{~m}$ in our vertical line, the upper section can be regarded as the middle level tide zone. Since the start-point of the vertical line was set at the end of the gravel beach with a height of 1 $\mathrm{m}$ or more (above the mean high water neap, including the spray zone), the red algae $P$. endiviifolia and Bangia atropurpurea, and the green alga Ulothrix sp., which are characteristic indicators of the high tide zone in King George Island, could not be identified.

A notable finding of this study was the relatively low algal coverage at the high tide levels (0-20 $\mathrm{m}$ range) in 2016-2017 (Fig. 1). When looking at the algal cover for the 2018-2019 season, it can be seen that low algal coverage does not follow an annual pattern. The variability in the total algal cover can be 
interpreted as inter-year variation, as in the case of Kim ${ }^{26}$ and Marcías, et al. ${ }^{27}$. Notably, the study site is designated an ice foot zone in winter, when ice disruption has a significant impact on benthic communities in the intertidal zone. Additional factors influencing benthic communities include disturbance by wave action, UV light, and ice. It has been shown that ice influences are greater than wave action at about $60^{\circ} \mathrm{S}^{30}$. The ice foot causes major disturbance in the intertidal zone, and the influence of ice scouring is significant up to about $20 \mathrm{~m}$ depth in the subtidal zone around $60^{\circ} \mathrm{S}^{30}$. Ice scouring has a large effect on macroalgal vertical zonation and abundance in shallow Antarctic waters ${ }^{15,19,26,31}$. In our study area, macroalgal abundance is thought to be substantially affected by ice disturbance (both the ice foot and growlers). Thus, the macroalgal cover of the high level intertidal zone may fluctuate from yearto-year due to the large variations in sea ice formation and ice foot duration in this area. Notably, the bare space variance of the neighboring shore ${ }^{26}$ with a similar intertidal foundation matches the inter-year difference in macroalgal cover observed in our study. Stations $1-4{ }^{26}$, which are directly affected by the ice foot, are considered to be high tidal level zones indicating the low algal cover. Those were, implying that disturbances caused by ice throughout winter/spring 2016 had an impact on the total cover of our study site. Although there are several studies on the direct and indirect effects of ice scour in Antarctica ${ }^{30,32}$, only $\mathrm{Kim}^{26}$ has reported the quantitative consequences of the ice foot on the macroalgal assemblage of the intertidal zone. The quantitative correlation between ice disturbances and the abundance of macroalgae in the intertidal zone can be confirmed in the future through a long-term series of experiments using the "nail mortality" ${ }^{26}$ or "marker of plastic cup with concrete" 33 methods.

The temporal variation of the macroalgal assemblage calculated through SIMPER analysis was higher than the spatial variation shown for adjacent coasts (Table 2). The decrease in I. cordata and increase in Phaeurus antarcticus were the most important drivers of temporal variation in the intertidal zone. In other words, the macroalgal distribution in the study area shifted from I. cordata dominance in early summer to $P$. antarcticus dominance in January. Seasonal development of macroalgae is known to be influenced by light, temperature, and nutrient conditions ${ }^{34}$. Since temperature and nutrient supplies fluctuate little in Antarctica, light is expected to have the largest impact on seasonal development ${ }^{10}$. In terms of the seasonality of macroalgae due to the effects of light, l. cordata has been classified as a season responder and $P$. antarcticus as a season anticipator sensu stricto ${ }^{20}$. As a season responder, I. cordata has an opportunistic life strategy, directly responds to light availability under favorable light conditions ${ }^{10}$, and shows the maximum growth rate in the spring-summer (e.g., December) season ${ }^{2,21}$. These ecophysiological characteristics of $I$. cordata are in good agreement with our finding, which showed a decrease in coverage in January compared to November and December. In addition, because the fronds are not fully destroyed after summer and regrowth occurs in the perennial basal sections, I. cordata is a pseudo perennial species and a representative species of coastscapes in the study area ${ }^{27}$. By contrast, the growth and reproduction of $P$. antarcticus, as a season anticipator, are controlled by changes in day length or photoperiodism, with growth increases in the late winter/early spring and maximum growth occurring in spring ${ }^{10,35}$. Season anticipators start to grow earlier than season responders, although they are believed to have a k-selected strategy characterized by slow development and a longer life ${ }^{2}$. Thus, 
there may be an ecological explanation for the slower population expansion of $P$. antarcticus relative to $I$. cordata in this study. In addition, Palmaria decipiens, Desmarestia anceps, Ascoseira mirabillis, $D$.

antarctica, and $D$. menziesii, which are accepted as season anticipators ${ }^{2,10,20}$, were found to increase in January compared to November or December (Table 2), which can also be explained by the above reasons.

\section{Species composition and spatial variation in Maxwell Bay}

The spatial variation of the macroalgal assemblage in the two intertidal zones approximately $400 \mathrm{~m}$ apart showed dissimilarity more than $20 \%$ numerically by SIMPER. Nevertheless, distinct differences in ecological indices, such as richness, diversity, or evenness, could not be found. The main distinction between the sites is that site $\mathrm{A}$ has more reddish coastscapes due to the presence of Palmaria decipiens. Looking at several previous intertidal studies of macroalgal assemblages or benthic communities associated with macroalgae conducted around Maxwell Bay 25-28,36,37, the assemblages differed from our findings and revealed significant heterogeneity between studies (Fig. 2). In a study conducted in January 1997 at a beach $1.5 \mathrm{~km}$ away from our study site ${ }^{26}$, Adenocystis utricularis, l. cordata, $P$. decipiens, Monostroma hariotii, Acrosiphonia arcta, and Pyropia endiviifolium were found. Although this list of species is identical to ours, the dominant species composition was different: at that time, green $M$. hariotii $(18.0 \%$ cover) and brown $A$. utricularis ( $15.9 \%$ cover) were the dominant species. As the field color of $A$. utricularis was olive green, the coastscape would have been lush green. Marcías, et al. ${ }^{27}$ conducted a macroalgal assemblage survey (Jan. 2009) of an intertidal zone about $3 \mathrm{~km}$ across Potter Cove from our study area. Palmaria decipiens and $A$. utricularis dominated in the middle level, while I. cordata and Phaeurus antarcticus dominated in the lower level. Notably, the macroalgal assemblage in the lower part was similar to our findings. Moreover, $A$. utricularis and Urospora penicilliformis appeared (Dec. 2013 to Feb. 2014) exclusively on the emergent rock in the intertidal zone northeast of Fildes Bay, about $10 \mathrm{~km}$ from the Barton Peninsula; in the tide pool, CCA was the predominant species and I. cordata and $A$. utricularis were mainly distributed ${ }^{37}$. Valdivia, et al. ${ }^{28}$ reported that Ulothrix sp. and U. penicilliformis were mostly found in six intertidal zones on the Fildes Peninsula (Jan. 2013). It is worth noting that the spatial variation of the macroalgal assemblage between the earlier studies and our study is quite different.

Spatial variability revealed numerous dissimilarities of the assemblages by the sampled scales. Coleman ${ }^{38}$ surveyed macroalgal assemblage at multiple scales, such as quadrats $(10 \mathrm{~cm})$, sites $(10 \mathrm{~m})$, locations (kilometers apart), and habitats (intertidal and subtidal), and found that habitats or locations had the most variety. Nevertheless, it is documented that spatial variability accounts for the highest proportion when measured in tens of centimeters (small scale), and that dissimilarity is increased when the scale is increased. The macroalgal assemblages show scale-dependent spatial variability; if variability on a small scale is considered to be noise, variability on a larger scale may be misinterpreted. In order to detect changes in the assemblage in response to environmental impact, it is critical to first identify the scale of 
variation ${ }^{39,40}$. According to the conceptual model of general meta-ecosystems, environmental processes act on the macroscale (100s of $\mathrm{km}$ ) to mesoscale (10s of $\mathrm{km}$ ) community, whereas ecological processes have larger effects on the local (100s of $\mathrm{m}$ ) scale ${ }^{41}$. For the spatial expansion of spatial variability for the macroalgal assemblage, we compared the similarity (CLUSTER analysis) among assemblage sites based on previous studies around Maxwell Bay and our results (Fig. 2). Although multiple environmental conditions, such as tide level, substrate, ice scouring, and wave action, were not taken into account, grouping (group A, B, C, and D by SIMPROF; Fig. 2 in dendrogram) of the macroalgal assemblage was confirmed to have been performed at the local scale (from $100 \mathrm{~s}$ of $m$ to single-digit km). The similarity of the assemblages decreased with increased distance among sites (or groups). Even on the local scale, the macroalgal assemblage of Maxwell Bay, King George Island, showed considerable heterogeneity. Looking closer, as for the similarity compared between sites, the heterogenous of assemblage increases as the scale increases, but dissimilarity does not seem to occupy the highest proportion on a small scale. As for the similarity compared between sites, the heterogenous of assemblage increases as the scale increases, but dissimilarity does not seem to occupy the highest proportion on a small scale.

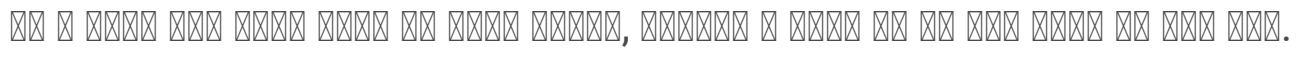

The site is a similarity comparison between heterogenous of assemblage increases as the scale increases, but in small scale does not seem to be the dissimilarity occupied the highest proportion.

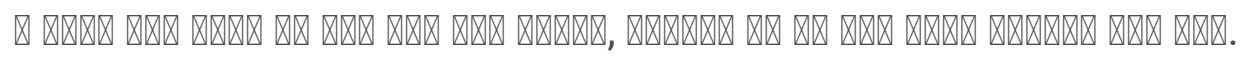

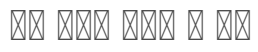

\section{讴讴}

㽖区...

$\mathbb{Q} \otimes \mathbb{Q} \otimes$

The local assemblage appears to differ both within and among groups (by SIMPROF). The similarity between groups or within groups based on connectivity could not be interpreted in our literature-based approach. However, based on the conceptual model of the meta-ecosystem ${ }^{41}$, the local-scale process seems to be dominant in Maxwell Bay. Studies on the variability of the assemblage within scales and among scales, and the conceptual model of the meta-ecosystem applied in the context of temperate regions, may not be suitable for assessing the macroalgal assemblage in an Antarctic environment. The main factors affecting the macroalgal assemblage in the Antarctic intertidal zone include day length, growler ice disturbance, water temperature, salinity, light, and temperature $2,10,35,42$. As the environmental conditions in Antarctica are quite different from those in low latitude areas, it is necessary to consider the scale of sampling for future studies of the macroalgal assemblage in this unique region. 


\section{Warming and the future of intertidal macroalgae in Maxwell Bay}

Global warming and climate change have posed threats to ecosystems due to increases in greenhouse gases since the Industrial Revolution; in the worst case scenario, the sea surface temperatures is expected to increase by nearly $6^{\circ} \mathrm{C}$ by the end of the 21 st century ${ }^{43,44}$. As global warming has the potential to cause catastrophic disasters, the " $1.5^{\circ} \mathrm{C}$ global warming scenario" was proposed at the Paris Climate Convention to prevent such events. Even under the $1.5^{\circ} \mathrm{C}$ scenario, 130 days of the year will be above $0^{\circ} \mathrm{C}$ in the north of the Antarctic Peninsula, resulting in new habitats being created due to ice melting ${ }^{45}$. The consequences of Antarctic warming are that ice scour and ocean acidification will intensify, and the increased seabed temperature will threaten benthic communities ${ }^{46}$. There will also be a southwards range shift of various species ${ }^{47}$. Research to date shows that newly introduced coldtemperate species are rare in Antarctica, but invasions and expansions of non-endemic species will occur sooner or later, so tipping points where rapid changes occur should not be overlooked ${ }^{45}$. Iridaea cordata and Phaeurus antarcticus are the predominant macroalgal species in the intertidal zone identified in this study. Non-endemic I. cordata is a season responder and distributed from intertidal to subtidal zones, while endemic $P$. antarcticus is a season anticipator distributed mainly in the subtidal zone $13,20,48,49$. While $I$. cordata is mainly distributed in Antarctica, it is also distributed in Auckland, New Zealand and the western coast of South America at $41^{\circ} \mathrm{S}$, and is thus a species with a relatively wider temperature tolerance than $P$. antarcticus ${ }^{49}$. Therefore, under the $1.5^{\circ} \mathrm{C}$ scenario, expansion of the $I$. cordata population can be expected. In the Arctic, as global warming continues, it is reported that perennial algae distributed in the subtidal zone are expanding to the intertidal zone and that biomass and algal diversity are increasing 50,51 . While $P$. antarcticus is mainly distributed in the subtidal zone in Antarctica, and dominantly distributed in the lower intertidal zone of our study area, it is also expected that this population will expand in the future. As shown in the literature, the optimal growth temperature (OGT) range for gametophytes of $I$. cordata and sporophytes of $P$. antarcticus is $0^{\circ} \mathrm{C}-5^{\circ} \mathrm{C}$ and the upper survival temperature (UST) is $15^{\circ} \mathrm{C}-16^{\circ} \mathrm{C}$; thus, the response to global warming is likely to be similar for these two species. However, considering the actual distribution ranges, superiority of the $I$.

cordata population can be expected ${ }^{49,52,53}$. Ascoseira mirabillis and Palmaria decipiens also have an OGT of $0^{\circ} \mathrm{C}-10^{\circ} \mathrm{C}$ and the UST is known to be $11^{\circ} \mathrm{C}$ and $16^{\circ} \mathrm{C}-17^{\circ} \mathrm{C}$, respectively; by contrast, the OGT and UST of Adenocystis utricularis are $0^{\circ} \mathrm{C}-15^{\circ} \mathrm{C}$ and $18^{\circ} \mathrm{C}$ or $19^{\circ} \mathrm{C}$, respectively. Therefore, A. mirabillis, $P$. decipiens, and $A$. utricularis may be more sensitive to warming than the predominant species and have a competitive advantage in the near future conditions. Although ultraviolet B-rays, water temperature, sea ice conditions, and wave action are independent factors that influence the distribution of the macroalgal assemblage in Antarctica, they also have multifactorial interactive effects on the assemblage ${ }^{54}$. Thus, it is difficult to predict the future macroalgal assemblage due to indirect effects such as ecological interactions 55 .

\section{Suggestions for the Antarctic specially protected area}


This research area, which is located south of the Barton Peninsula on King George Island and measures a few kilometers long by about $100 \mathrm{~m}$ wide, has higher macroalgal richness than other sites on King George Island. In the highest level of the intertidal zone, macroalgae that have fallen out of the substrate form a mat with a thickness of several tens of centimeters. These algal mats and moss beds in the spray zone are used as resting beds by elephant seals (Mirounga leonine) and Antarctic fur seals

(Arctocephalus gazella). Since the establishment of KSS in 1988, despite the official name being Winship Point (United Kingdom Antarctic Place-Names Committee; UK-APC), Koreans have referred to this area as "Haepyomaeul," which means "seal-village." In addition, many skua nests are found on the nearby hills. To date, the intertidal organisms in this area have received less attention than the terrestrial organisms. While the present study has documented various intertidal algae, a study on the mass distribution of specific $P$. antarcticus species in the intertidal zone is needed. We propose that Antarctic Specially Protected Area no. 171 (ASPA; Narebski Point, 62 ${ }^{\circ} 14^{\prime} 03^{\prime \prime}$ S, 58 $46^{\prime} 05^{\prime \prime} \mathrm{W}$ ) be expanded to include our research site because it is an ideal location for studying interactions between terrestrial and marine organisms through food web and nutrient flow studies.

\section{Declarations}

\section{Acknowledgments}

This work was supported by a grant from the Basic Research Program (PE21110 and PE21140) of the Korea Polar Research Institute. We would like to give special thanks to the $29^{\text {th }}$ overwintering team in King Sejong Station for helping us set up this experiment.

\section{Author information}

\section{Affiliations}

Division of Life Sciences, Korea Polar Research Institute, Incheon 21990, Republic of Korea

Young Wook Ko, Sanghee Kim, Han-Gu Choi

Department of Biological Sciences, Sungkyunkwan University, Suwon 16419, Republic of Korea

Dong Seok Lee, Jeong Ha Kim

\section{Contributions}

Y.W.K., H-G.C., S. K., J.H.K., conceived the study design and conceived ideas; Y.W.K., D.S.L., collected samples; Y.W.K., H-G.C., analysed the data; Y.W.K., H-G.C., contributed to interpretation of results; Y.W.K., HG.C., S. K., wrote the manuscript. All authors contributed to the final version of the manuscript.

\section{Corresponding author}

Correspondence to Han-Gu Choi 


\section{Ethics declarations}

\section{Competing Interests}

The authors declare no competing interests

\section{References}

1. Amsler, C. D. et al. Comprehensive evaluation of the palatability and chemical defenses of subtidal macroalgae from the Antarctic Peninsula. Mar Ecol Prog Ser 294, 141-159, doi:https://doi.org/10.3354/meps294141 (2005).

2. Gómez, I. \& Huovinen, P. Antarctic Seaweeds: Biogeography, Adaptation, and Ecosystem Services in Antarctic Seaweeds (eds Iván Gómez \& Pirjo Huovinen) Ch. 1, 3-20 (Springer, 2020).

3. Iken, K. Feeding ecology of the Antarctic herbivorous gastropod Laevilacunaria antarctica Martens. $J$ Exp Mar Biol Ecol 236, 133-148, doi:https://doi.org/10.1016/S0022-0981(98)00199-3 (1999).

4. Nedzarek, A. \& Rakusa-Suszczewski, S. Decomposition of macroalgae and the release of nutrient Admiralty Bay, King George, Antarctica. Polar Biosci 17, 26-35 (2004).

5. Oliveira, E. C., Absher, T. M., Pellizzari, F. M. \& Oliveira, M. C. The seaweed flora of Admiralty Bay, King George Island, Antarctic. Polar Bio/ 32, 1639-1647, doi:https://doi.org/10.1007/s00300-009-0663-9 (2009).

6. Wiencke, C. \& Clayton, M. N. Antarctic seaweeds in Synopses of the Antarctic Benthos Vol. 9 (eds J. W. Wägele \& J. Sieg) 239 (Koeltz Scientific Books, 2002).

7. Wiencke, C., Amsler, C. D. \& Clayton, M. N. Macroalgae in Biogeographic atlas of the Southern Ocean (eds Claude De Broyer et al.) 66-73 (Cambridge, Scientific Committee on Antarctic Research, 2014).

8. Wulff, A. et al. Biodiversity, biogeography and zonation of marine benthic micro- and macroalgae in the Arctic and Antarctic. Bot Mar 52, 491-507, doi:https://doi.org/10.1515/Bot.2009.072 (2009).

9. Waters, J. M. et al. Australia's marine biogeography revisited: Back to the future? Austral Eco/35, 988-992, doi:https://doi.org/10.1111/j.1442-9993.2010.02114.x (2010).

10. Wiencke, C. et al. Life strategy, ecophysiology and ecology of seaweeds in polar waters. Rev Environ Sci Bio 6, 95-126, doi:https://doi.org/10.1007/s11157-006-9106-z (2007).

11. Moe, R. L. \& Silva, P. C. Antarctic marine flora: uniquely devoid of kelps. Science 196, 1206-1208, doi:https://doi.org/10.1126/science.196.4295.1206 (1977).

12. Cormaci, M., Furnari, G. \& Scammacca, B. The benthic algal flora of Terra Nova Bay (Ross Sea, Antarctica). Bot Mar 35, 541-552, doi:https://doi.org/10.1515/botm.1992.35.6.541 (1992).

13. Cormaci, M., Furnari, G., Scammacca, B. \& Alongi, G. Summer biomass of a population of Iridaea cordata (Gigartinaceae, Rhodophyta) from Antarctica. Hydrobiologia 326/327, 267-272, doi:https://doi.org/10.1007/978-94-009-1659-3_37 (1996).

14. Miller, K. A. \& Pearse, J. S. Ecological studies of seaweeds in McMurdo Sound, Antarctica. Am Zool 31, 35-48, doi:https://doi.org/10.1093/icb/31.1.35 (1991). 
15. Gutt, J. On the direct impact of ice on marine benthic communities, a review. Polar Bio/ 24, 553-564, doi:https://doi.org/10.1007/s003000100262 (2001).

16. Klöser, H., Quartino, M. L. \& Wiencke, C. Distribution of macroalgae and macroalgal communities in gradients of physical conditions in Potter Cove, King George Island, Antarctica. Hydrobiologia 333, 117, doi:https://doi.org/10.1007/BF00020959 (1996).

17. Moe, R. \& DeLaca, T. Occurrence of macroscopic algae along the Antarctic Peninsula. Antarct J US 11, 20-24 (1976).

18. Smale, D. A., Brown, K. M., Barnes, D. K., Fraser, K. P. \& Clarke, A. Ice scour disturbance in Antarctic waters. Science 321, 371-371, doi:https://doi.org/10.1126/science.1158647 (2008).

19. Deregibus, D., Quartino, M. L., Zacher, K., Campana, G. L. \& Barnes, D. K. Understanding the link between sea ice, ice scour and Antarctic benthic biodiversity-the need for cross-station and international collaboration. Polar Rec 53, 143-152, doi:https://doi.org/10.1017/S0032247416000875 (2017).

20. Kain, J. M. The seasons in the subtidal. Brit Phycol J 24, 203-215, doi:https://doi.org/10.1080/00071618900650221 (1989).

21. Wiencke, C. Seasonality of brown macroalgae from Antarctica-a long-term culture study under fluctuating Antarctic daylengths. Polar Bio/ 10, 589-600, doi:https://doi.org/10.1007/Bf00239370 (1990).

22. Locarnini, M. et al. World Ocean Atlas 2018, Volume 1: Temperature. A. Mishonov, Technical Editor. NOAA Atlas NESDIS 81, 52pp. https://archimer.ifremer.fr/doc/00651/76338/ (2019).

23. Underwood, A. J. Experimental ecology of rocky intertidal habitats: what are we learning? J Exp Mar Biol Ecol 250, 51-76, doi:https://doi.org/10.1016/S0022-0981(00)00179-9 (2000).

24. Jazdzewski, K., De Broyer, C., Pudlarz, M. \& Zielinski, D. Seasonal fluctuations of vagile benthos in the uppermost sublittoral of a maritime Antarctic fjord in Ecological Studies in the Antarctic Sea Ice Zone (eds Wolf E. Arntz \& Andrew Clarke) 89-96 (Springer-Verlag Berlin Heidelberg, 2002).

25. Martín, A. et al. Intertidal benthic communities associated with the macroalgae Iridaea cordata and Adenocystis utricularis in King George Island, Antarctica. Polar Bio/ 39, 207-220, doi:https://doi.org/10.1007/s00300-015-1773-1 (2016).

26. Kim, D. Seasonality of marine algae and grazers of an Antarctic rocky intertidal, with emphasis on the role of the limpet Nacella concinna Strebel (Gastropoda: Patellidae). Report No. 397, 120 (Alfred Wegener Institute for Polar and Marine Research, Bremerhaven, 2001).

27. Marcías, M. L., Deregibus, D., Saravia, L. A., Campana, G. L. \& Quartino, M. L. Life between tides: spatial and temporal variations of an intertidal macroalgal community at Potter Peninsula, South Shetland Islands, Antarctica. Estuar Coast Shelf S 187, 193-203, doi:https://doi.org/10.1016/j.ecss.2016.12.023 (2017).

28. Valdivia, N. et al. Up, down, and all around: scale-dependent spatial variation in rocky-shore communities of Fildes Peninsula, King George Island, Antarctica. PLoS One 9, e100714, doi:https://doi.org/10.1371/journal.pone.0100714 (2014). 
29. Zacher, K., Wulff, A., Molis, M., Hanelt, D. \& Wiencke, C. Ultraviolet radiation and consumer effects on a field-grown intertidal macroalgal assemblage in Antarctica. Glob Change Biol 13, 1201-1215, doi:https://doi.org/10.1111/j.1365-2486.2007.01349.x (2007).

30. Barnes, D. K. \& Conlan, K. E. Disturbance, colonization and development of Antarctic benthic communities. Philos T Roy Soc B 362, 11-38, doi:https://doi.org/10.1098/rstb.2006.1951 (2007).

31. Clark, G. F., Stark, J. S., Perrett, L. A., Hill, N. A. \& Johnston, E. L. Algal canopy as a proxy for the disturbance history of understorey communities in East Antarctica. Polar Bio/34, 781-790, doi:https://doi.org/10.1007/s00300-010-0931-8 (2011).

32. Smale, D. A. Ice disturbance intensity structures benthic communities in nearshore Antarctic waters. Mar Ecol Prog Ser 349, 89-102, doi:https://doi.org/10.3354/meps07104 (2007).

33. Brown, K. M., Fraser, K. P., Barnes, D. K. \& Peck, L. S. Links between the structure of an Antarctic shallow-water community and ice-scour frequency. Oecologia 141, 121-129, doi:https://doi.org/10.1007/s00442-004-1648-6 (2004).

34. Lobban, C. S. \& Harrison, P. J. Seaweed Ecology and Physiology. (Cambridge University Press, 1994).

35. Wiencke, C., Gómez, I. \& Dunton, K. Phenology and seasonal physiological performance of polar seaweeds. Bot Mar 52, 585-592, doi:https://doi.org/10.1515/Bot.2009.078 (2009).

36. Aghmich, A., Taboada, S., Toll, L. \& Ballesteros, M. First assessment of the rocky intertidal communities of Fildes Bay, King George Island (South Shetland Islands, Antarctica). Polar Bio/39, 189-198, doi:https://doi.org/10.1007/s00300-015-1814-9 (2016).

37. Segovia-Rivera, V. \& Valdivia, N. Independent effects of grazing and tide pool habitats on the early colonisation of an intertidal community on western Antarctic Peninsula. Rev Chil Hist Nat 89, 1-9, doi:https://doi.org/10.1186/s40693-016-0053-y (2016).

38. Coleman, M. Small-scale spatial variability in intertidal and subtidal turfing algal assemblages and the temporal generality of these patterns. J Exp Mar Biol Ecol 267, 53-74, doi:https://doi.org/10.1016/S0022-0981(01)00358-6 (2002).

39. Underwood, A. J. The mechanics of spatially replicated sampling programmes to detect environmental impacts in a variable world. Aust J Ecol 18, 99-116, doi:https://doi.org/10.1111/j.1442-9993.1993.tb00437.x (1993).

40. Underwood, A. J. On beyond BACl: sampling designs that might reliably detect environmental disturbances. Ecol App/ 4, 3-15, doi:https://doi.org/10.2307/1942110 (1994).

41. Menge, B. A., Gouhier, T. C., Hacker, S. D., Chan, F. \& Nielsen, K. J. Are meta-ecosystems organized hierarchically? A model and test in rocky intertidal habitats. Ecol Monogr 85, 213-233, doi:https://doi.org/10.1890/14-0113.1 (2015).

42. Schroeter, B., Olech, M., Kappen, L. \& Heitland, W. Ecophysiological investigations of Usnea antarctica in the maritime Antarctic I. Annual microclimatic conditions and potential primary production. Antarct Sci 7, 251-260, doi:https://doi.org/10.1017/S0954102095000356 (1995).

43. Aral, M. M. \& Guan, J. Global sea surface temperature and sea level rise estimation with optimal historical time lag data. Water-Sui 8, 519, doi:https://doi.org/10.3390/w8110519 (2016). 
44. IPCC. Climate Change 2013: The Physical Science Basis. Contribution of Working Group I to the Fifth Assessment Report of the Intergovernmental Panel on Climate Change. 1535 (Cambridge university press, Cambridge, United Kingdom and New York, NY, USA, 2013).

45. Siegert, M. J. et al. The Antarctic Peninsula under a $1.5^{\circ} \mathrm{C}$ global warming scenario. Front Env SciSwitz 7, 102, doi:https://doi.org/10.3389/fenvs.2019.00102 (2019).

46. Turner, J. et al. Antarctic climate change and the environment: an update. Polar Rec 50, 237-259, doi:https://doi.org/10.1017/S0032247413000296 (2013).

47. Constable, A. J. et al. Climate change and Southern Ocean ecosystems I: how changes in physical habitats directly affect marine biota. Glob Change Biol 20, 3004-3025, doi:https://doi.org/10.1111/gcb.12623 (2014).

48. Clayton, M. \& Wiencke, C. The anatomy, life history and development of the Antarctic brown alga Phaeurus antarcticus (Desmarestiales, Phaeophyceae). Phycologia 29, 303-315, doi:https://doi.org/10.2216/i0031-8884-29-3-303.1 (1990).

49. Wiencke, C. \& Dieck, I. T. Temperature requirements for growth and survival of macroalgae from Antarctica and southern Chile. Mar Ecol Prog Ser 59, 157-170, doi:https://doi.org/10.3354/meps059157 (1990).

50. Węsławski, J. M. et al. Climate change effects on Arctic fjord and coastal macrobenthic diversityobservations and predictions. Mar Biodivers 41, 71-85, doi:https://doi.org/10.1007/s12526-0100073-9 (2011).

51. Węsławski, J. M., Wiktor, J. \& Kotwicki, L. Increase in biodiversity in the arctic rocky littoral, Sorkappland, Svalbard, after 20 years of climate warming. Mar Biodivers 40, 123-130, doi:https://doi.org/10.1007/s12526-010-0038-z (2010).

52. Wiencke, C., Bartsch, I., Bischoff, B., Peters, A. F. \& Breeman, A. Temperature requirements and biogeography of Antarctic, Arctic and amphiequatorial seaweeds. Bot Mar 37, 247-260, doi:https://doi.org/10.1515/botm.1994.37.3.247 (1994).

53. Wiencke, C. \& Tom Dieck, I. Temperature requirements for growth and temperature tolerance of macroalgae endemic to the Antarctic region. Mar Ecol Prog Ser 54, 189-197, doi:https://doi.org/10.3354/meps054189 (1989).

54. Bartsch, I., Wiencke, C. \& Laepple, T. Global seaweed biogeography under a changing climate: the prospected effects of temperature in Seaweed Biology (eds Christian Wiencke \& Kai Bischof) 383406 (Springer, 2012).

55. Schiel, D. R., Steinbeck, J. R. \& Foster, M. S. Ten years of induced ocean warming causes comprehensive changes in marine benthic communities. Ecology 85, 1833-1839, doi:https://doi.org/10.1890/03-3107 (2004).

56. Yoo, C.-M., Choe, M.-Y., Jo, H.-R., Kim, Y.-D. \& Kim, K.-H. Volcaniclastic sedimentation of the Sejong Formation (Late Paleocene-Eocene), Barton Peninsula, King George Island, Antarctica. Ocean Polar Res 23, 97-107 (2001). 
57. Guiry, M. D. \& Guiry, G. World-wide electronic publication, National University of Ireland, Galway. https://www.algaebase.org; searched on 07 May 2021.

58. Clarke, K. R., Gorley, R., Somerfield, P. J. \& Warwick, R. Change in marine communities: an approach to statistical analysis and interpretation. 3rd edn, (PRIMER-E Ltd, Plymouth, 2014).

59. Matsuoka, K. et al. Quantarctica, an integrated mapping environment for Antarctica, the Southern Ocean, and sub-Antarctic islands. Environ Model Softw 140, 105015, doi:https://doi.org/10.1016/j.envsoft.2021.105015 (2021).

\section{Tables}

Table 1. Resemblance matrix of the macroalgal assemblage between sampling times ( 1 and 2 months) and sampling seasons (2016-17 and 2018-19). The open cells are the similarity between sampling times and the shaded cells are the similarity between sampling seasons.

\begin{tabular}{llllll} 
Similarity & & \multicolumn{2}{c}{$2018-19$ season } & \multicolumn{2}{l}{$2016-17$ season } \\
\cline { 2 - 5 } & & Dec. & Jan. & Nov & Jan \\
\hline $\begin{array}{c}\text { 2018-19 } \\
\text { season }\end{array}$ & Dec. & & & 65.98 & \\
\cline { 2 - 4 } & Jan. & 78.35 & & & \\
\hline $\begin{array}{c}2016-17 \\
\text { season }\end{array}$ & Nov. & 74.05 & 60.94 & \\
\cline { 2 - 5 } & Jan. & 64.46 & 64.48 & 64.61
\end{tabular}

Table 2. Short-term variation in the mean cover of all species in the macroalgal assemblage and SIMPER (similarity of percentage) contribution of all species between sampling times in the intertidal zone of the southwest coast of the Barton Peninsula, King George Island, Antarctica. 
Species $^{a}$

Sampling season

2018-19

2016-17

Sampling time

Dec. ${ }^{\mathrm{b}} \quad$ Jan. ${ }^{\mathrm{b}} \quad$ Cont. Nov. ${ }^{\mathrm{b}}$ Jan. ${ }^{\mathrm{b}}$ Cont.

$(\%)^{\mathrm{c}} \quad(\%)^{\mathrm{c}}$

Iridaea cordata (R/NE)

$34.07 \pm$

6.67

$25.54 \pm$

13.3

$34.96 \pm$

$18.69 \pm$

22.46

Phaeurus

antarcticus (A/E)

$14.07 \pm$

6.12

4.65

7.20

3.85

$21.93 \pm$

5.89

$5.43 \pm$

2.28

$41.38 \pm$

31.32

Palmaria decipiens (A/NE)

$14.43 \pm$

$14.54 \pm$

3.39

$0.04 \pm$

10.9

4.46

3.58

0.04

$0.38 \pm$

0.26

3.23

Desmarestia

$0.50 \pm$

$9.75 \pm$

0.36

3.79

23.64

$0.62 \pm \quad 1.06 \pm$

0.86

anceps (A/NE)

$2.50 \pm$

$1.43 \pm$

5.35

0.48

1.06

Crustose coralline algae

0.73

0.34

$\begin{array}{ll}4.26 \pm & 0.94 \pm \\ 0.84 & 0.30\end{array}$

12.42

\begin{tabular}{llll}
$\begin{array}{l}\text { Adenocystis } \\
\text { utricularis (R/NE) }\end{array}$ & $0.93 \pm$ & $0.54 \pm$ & 3.21 \\
Ascoseira mirabilis (A/E) & $1.68 \pm$ & $3.39 \pm$ & 4.28 \\
& 1.04 & 1.42 & \\
\hline $\begin{array}{l}\text { Desmarestia } \\
\text { antarctica (A/E) }\end{array}$ & - & $3.11 \pm$ & 17.74 \\
$\begin{array}{l}\text { Desmarestia } \\
\text { menziesii (A/E) }\end{array}$ & $0.11 \pm$ & $2.11 \pm$ & 10.97 \\
$\begin{array}{l}\text { Monostroma } \\
\text { hariotii (?/NE) }\end{array}$ & 0.11 & 1.85 & \\
$\begin{array}{l}\text { Plocamium } \\
\text { cartilagineum (?/NE) }\end{array}$ & $0.50 \pm$ & $0.29 \pm$ & 5.57 \\
\hline
\end{tabular}

Halopteris obovata (?/NE)

$\begin{array}{ll}1.02 \pm & 3.81 \pm \\ 0.21 & 2.03\end{array}$

6.47

10.11

$1.02 \pm$
1.02

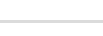

10.11
$\pm \quad 0.06$

$-$

\section{Phycodrys}

antarctica (?/E)

$\begin{array}{ll}\text { Ulva hookeriana (R/NE) } & 0.07 \pm \\ 0.07\end{array}$

Geogiella confluens (?/E)

$0.11 \pm$

0.05

$0.09 \pm$

0.04

$0.13 \pm$

0.06

0.13 


\begin{tabular}{lllll}
\hline Diversity $\left(\mathrm{H}^{\prime}\right)$ & 1.381 & 1.753 & 0.979 & 0.984 \\
\hline Evenness $\left(\mathrm{J}^{\prime}\right)$ & 0.600 & 0.731 & 0.382 & 0.555 \\
\hline Dissimilarity & 21.65 & & \multicolumn{2}{c}{35.39}
\end{tabular}

${ }^{a}$ Life strategy and endemism of the macroalgal species. Abbreviations: R: season responder, A: season anticipator, E: Antarctic endemic species, NE: non-endemic species,?: life strategy is unknown. Reference from Kain (1989) ${ }^{20}$, Wiencke et al. (2007) ${ }^{10}$, and Gómez and Huovinen (2020) ${ }^{2}$

${ }^{b}$ Mean coverage of the species \pm standard error

${ }^{\mathrm{c}}$ Percentage of SIMPER contribution to dissimilarity between sampling times ( 1 month and 2 months)

Table 3. Spatial variation in the mean cover of all species in the macroalgal assemblage, relative coverage (RC), and SIMPER (similarity of percentage) contribution of all species between the sampling sites in the intertidal zone of the southwest coast of the Barton Peninsula, King George Island, Antarctica. 


\begin{tabular}{llllll} 
Species & Site A & \multicolumn{2}{c}{ Site B } & \multirow{2}{*}{ Cont. (\%) ${ }^{\mathrm{b}}$} \\
\cline { 2 - 5 } & Mean ${ }^{\mathrm{a}}$ & $\mathrm{RC}$ & Mean ${ }^{\mathrm{a}}$ & $\mathrm{RC}$ & \\
\hline Iridaea cordata & $20.24 \pm 4.05$ & 36.0 & $18.88 \pm 2.78$ & 35.2 & 0.62 \\
\hline Phaeurus antarcticus & $21.97 \pm 4.98$ & 39.1 & $15.5 \pm 4.04$ & 28.9 & 7.79 \\
\hline Crustose coralline algae & $5.68 \pm 1.35$ & 10.1 & $9.74 \pm 1.45$ & 18.2 & 9.60 \\
\hline Desmarestia anceps & $1.00 \pm 0.51$ & 1.8 & $6.95 \pm 3.09$ & 13.0 & 20.10 \\
\hline Palmaria decipiens & $5.18 \pm 2.26$ & 9.2 & $0.19 \pm 0.19$ & 0.4 & 21.66 \\
\hline Adenocystis utricularis & $0.24 \pm 0.10$ & 0.4 & $0.74 \pm 0.22$ & 1.4 & 4.62 \\
\hline Desmarestia menziesii & - & - & $0.76 \pm 0.47$ & 1.4 & 10.56 \\
\hline Ulva hookeriana & $0.65 \pm 0.23$ & 1.2 & $0.14 \pm 0.07$ & 0.3 & 5.01 \\
\hline Gigartina skottsbergii & $0.74 \pm 0.38$ & 1.3 & $0.05 \pm 0.05$ & 0.1 & 7.47 \\
\hline Ascoseira mirabilis & $0.24 \pm 0.24$ & 0.4 & $0.38 \pm 0.24$ & 0.7 & 1.67 \\
\hline Monostroma hariotii & $0.12 \pm 0.09$ & 0.2 & $0.17 \pm 0.08$ & 0.3 & 0.89 \\
\hline Neuroglossum ligulatum & - & - & $0.12 \pm 0.12$ & 0.2 & 4.20 \\
\hline Paraglossum lancifolium & $0.12 \pm 0.08$ & 0.2 & - & - & 4.10 \\
\hline Desmarestia antarctica & - & - & $0.02 \pm 0.02$ & $<0.1$ & 1.71 \\
\hline Sum & $56.15 \pm 6.63$ & $100 \%$ & $53.64 \pm 5.22$ & $100 \%$ & 100 \\
\hline Richness (S) & 11 & & 13 & & \\
\hline Diversity (H') & 1.44 & & 1.53 & & \\
\hline Evenness (J') & 0.600 & & 0.597 & & \\
\hline (Dis)similarity & $77.13(22.87)$ & & & & \\
\hline & & & & & \\
\hline
\end{tabular}

${ }^{\text {a }}$ Mean coverage of the species \pm standard error

b Percentage of SIMPER contribution to dissimilarity between sampling sites

Table 4. Geographic information of the sites and sampling dates. 


\begin{tabular}{|c|c|c|c|c|c|c|c|}
\hline \multirow[t]{2}{*}{ Site } & \multicolumn{5}{|l|}{ Vertical line } & \multirow[t]{2}{*}{ Purpose } & \multirow[t]{2}{*}{ Date } \\
\hline & Start-point & Mid-point & End-point & $\begin{array}{l}\text { Length } \\
\text { (m) }\end{array}$ & $\begin{array}{l}\text { Interval } \\
(\mathrm{m})\end{array}$ & & \\
\hline \multirow[t]{5}{*}{$A$} & \multirow{5}{*}{$\begin{array}{l}62.24217^{\circ} \mathrm{S} \\
58.73384 \\
{ }^{\circ} \mathrm{W}\end{array}$} & \multirow{5}{*}{$\begin{array}{l}62.24270^{\circ} \mathrm{S} \\
58.73380 \\
{ }^{\circ} \mathrm{W}\end{array}$} & \multirow{5}{*}{$\begin{array}{l}62.24289^{\circ} \mathrm{S} \\
58.73379 \\
{ }^{\circ} \mathrm{W}\end{array}$} & 70 & 10 & \multirow{4}{*}{$\begin{array}{l}\text { Short- } \\
\text { term } \\
\text { variation }\end{array}$} & $\begin{array}{l}\text { 17-Nov- } \\
2016\end{array}$ \\
\hline & & & & 70 & 5 & & $\begin{array}{l}\text { 14-Jan- } \\
2017\end{array}$ \\
\hline & & & & 65 & 5 & & $\begin{array}{l}\text { 25-Dec- } \\
2018\end{array}$ \\
\hline & & & & 70 & 5 & & $\begin{array}{l}\text { 22-Jan- } \\
2019\end{array}$ \\
\hline & & & & 80 & 5 & \multirow{2}{*}{$\begin{array}{l}\text { Spatial } \\
\text { variation }\end{array}$} & 2-Jan-2018 \\
\hline B & $\begin{array}{l}62.24187^{\circ} \mathrm{S} \\
58.74095 \\
{ }^{\circ} \mathrm{W}\end{array}$ & & $\begin{array}{l}62.24274{ }^{\circ} \mathrm{S} \\
58.74144 \\
\circ \mathrm{W}\end{array}$ & 100 & 5 & & 4-Jan-2018 \\
\hline
\end{tabular}

Figures 

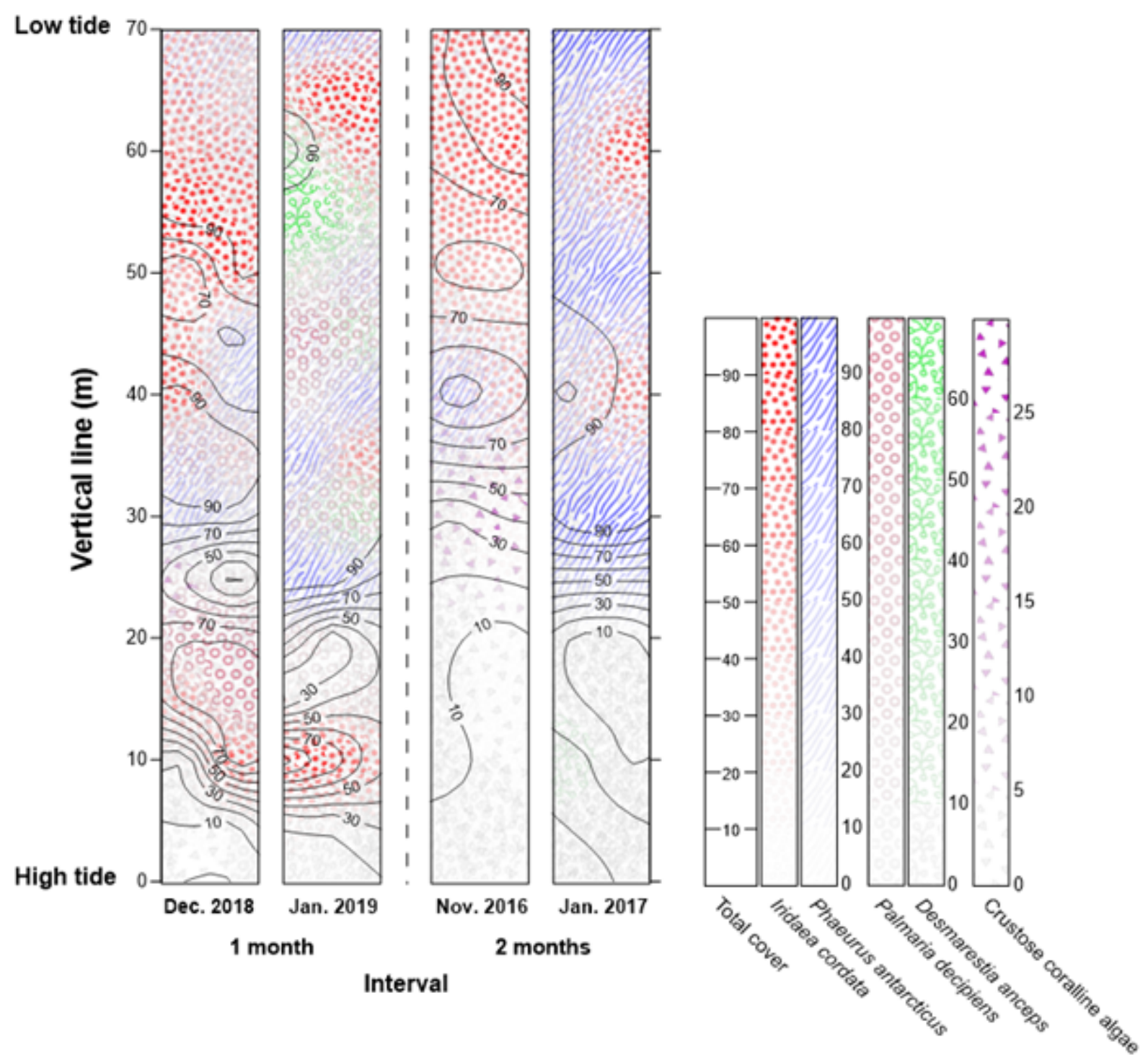

Figure 1

Contour plots of total algal cover and major species cover from the high tidal level to low tidal level between the sampling interval of the intertidal zone at Barton Peninsula, King George Island, Antarctica. The contour plots were created based on overlapping contour plots of the total algal cover and five major species cover. The contour line is the total macroalgal cover. The gradient-colored pattern is the cover of the major species. 


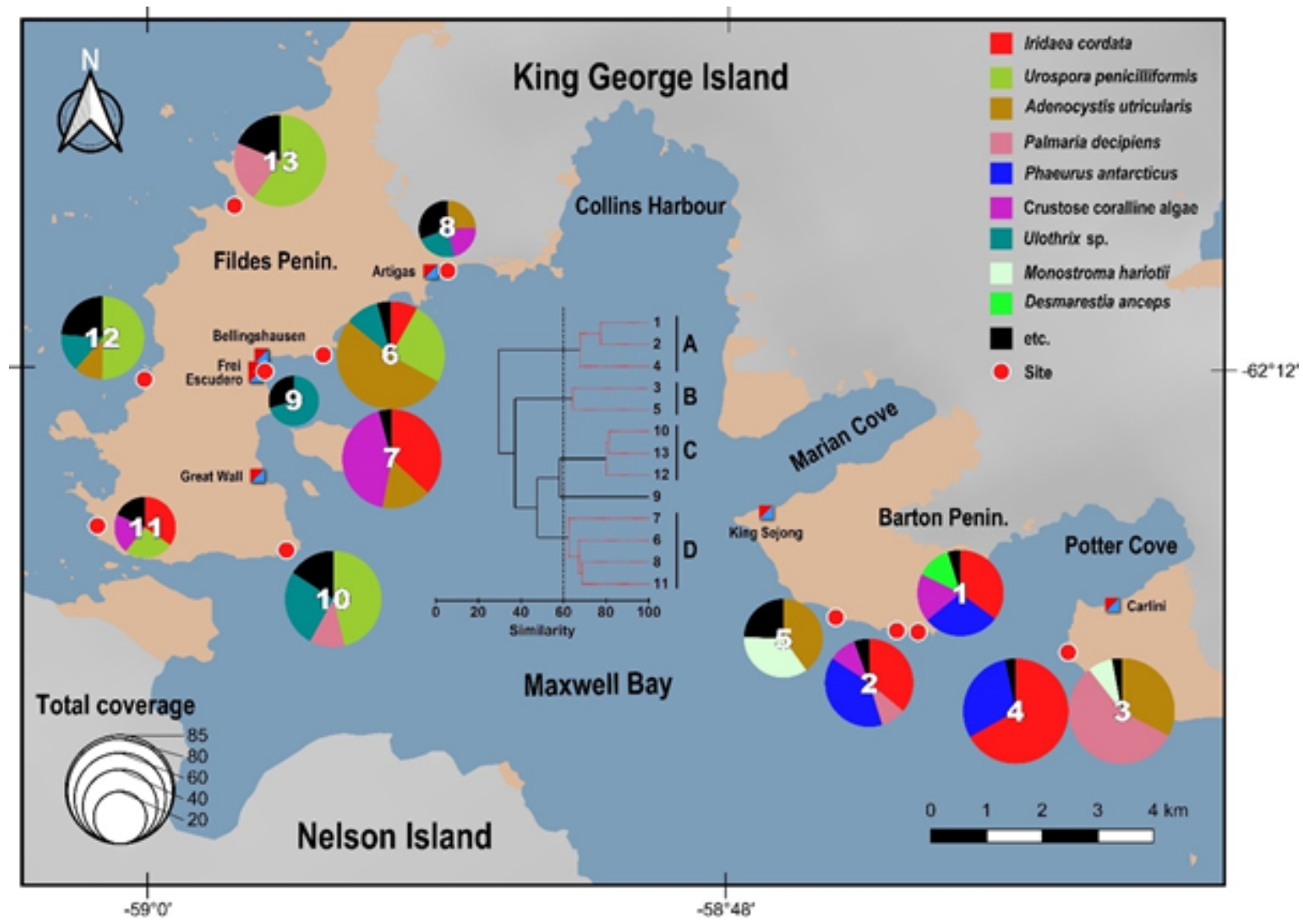

Figure 2

Species composition and spatial variation of the macroalgal assemblage on King George Island reported in the literature. 1-2: sites A and B, respectively, in the present study; 3-4: Marcías, et al. 27, mid- and low tidal zone, respectively; 5: Kim 26; 6-7: Segovia-Rivera and Valdivia 37, emergent rock and tide pool, respectively; and 8-13: Valdivia, et al. 28. For each survey site, species that showed more than $5 \%$ cover are independently expressed in the pie chart, and species with cover less than $5 \%$ are expressed as "etc." The dendrogram was generated by CLUSTER analysis of the similarity of the macroalgal assemblage between sites, and the structure between sites was derived through SIMPROF analysis. The red dotted line and letters $(A-D)$ indicate the groups by SIMPROF. Note: The designations employed and the presentation of the material on this map do not imply the expression of any opinion whatsoever on the part of Research Square concerning the legal status of any country, territory, city or area or of its authorities, or concerning the delimitation of its frontiers or boundaries. This map has been provided by the authors. 


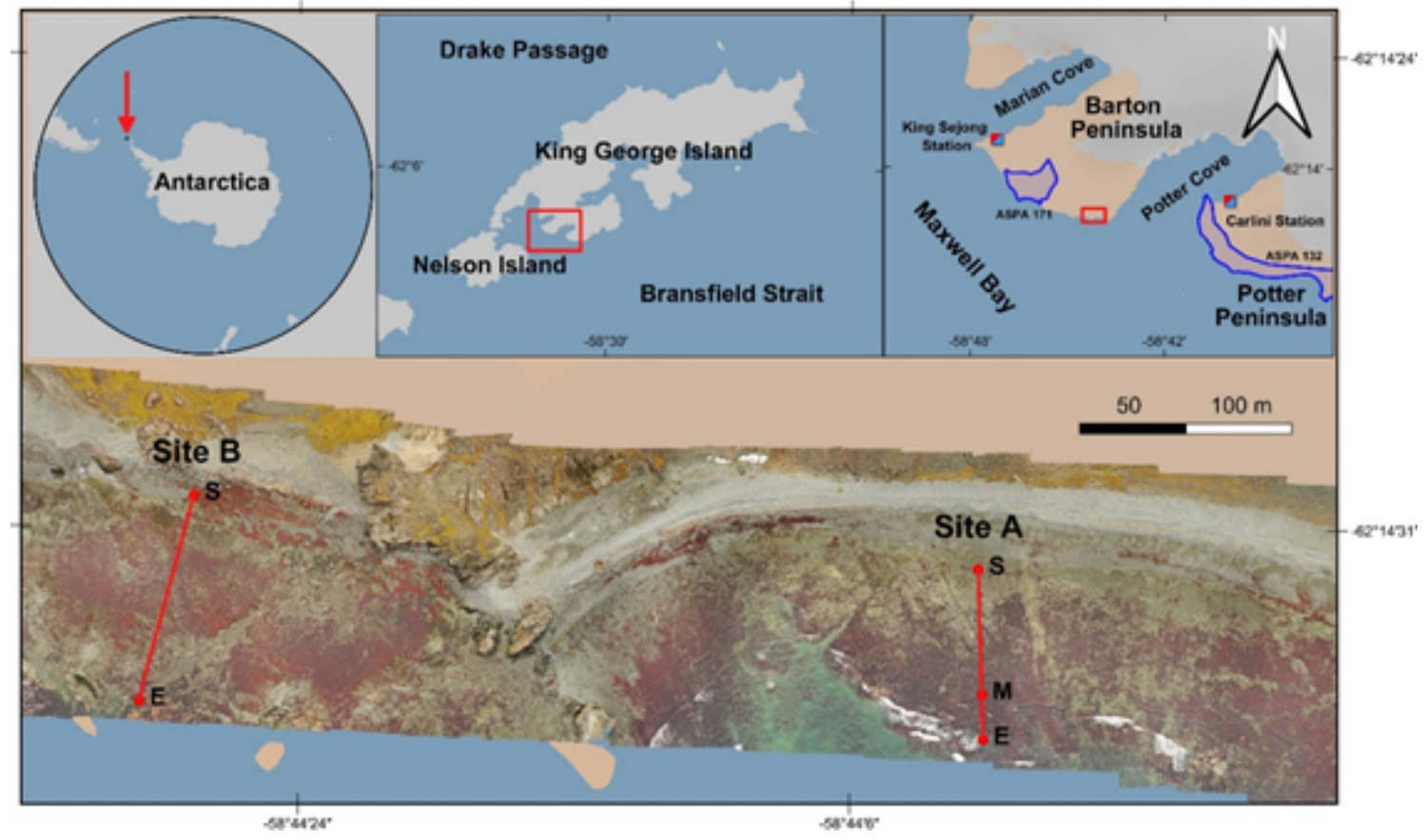

Figure 3

Sampling site at Barton Peninsula, King George Island. The red lines indicate the vertical line of each site. S: Start-point of the vertical line, M: Mid-point of the vertical line, E: End-point of vertical line. Source of map: Quantarctica 59 and 3D photogrammetry mapping using unmanned aerial vehicles (DJI Mavic 2 Pro). Note: The designations employed and the presentation of the material on this map do not imply the expression of any opinion whatsoever on the part of Research Square concerning the legal status of any country, territory, city or area or of its authorities, or concerning the delimitation of its frontiers or boundaries. This map has been provided by the authors. 

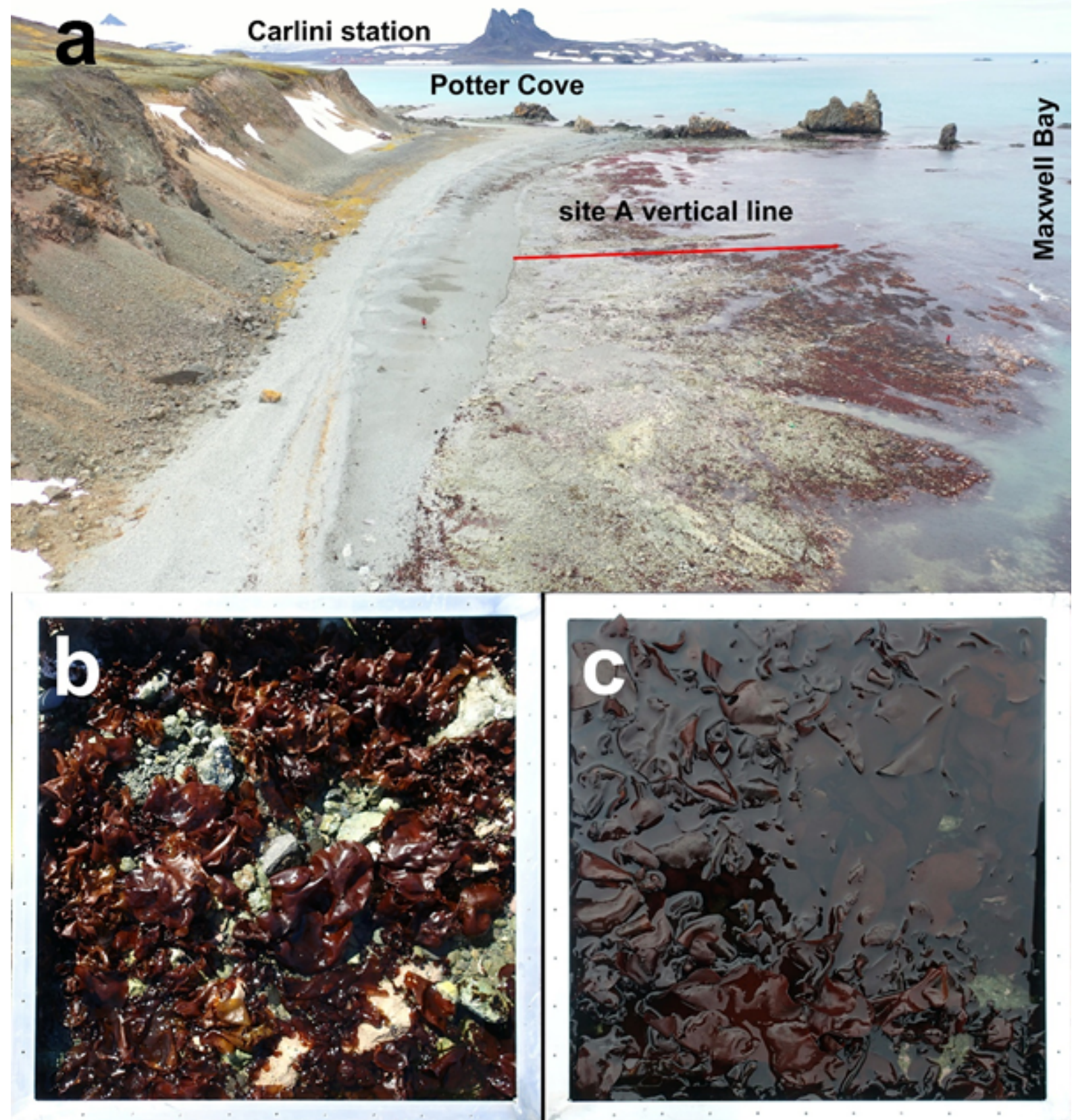

\section{Figure 4}

A view of the intertidal rocky platforms of site $A$ by an unmanned aerial vehicle (a). Changes in the macroalgal assemblage inside the plot dominated by Iridaea cordata before (b) and after (c) two months. The quadrat photo is the $60 \mathrm{~m}$ point of site A. The red line is the vertical line of site A. Note: The designations employed and the presentation of the material on this map do not imply the expression of any opinion whatsoever on the part of Research Square concerning the legal status of any country, territory, city or area or of its authorities, or concerning the delimitation of its frontiers or boundaries. This map has been provided by the authors.

\section{Supplementary Files}


This is a list of supplementary files associated with this preprint. Click to download.

- SupplementaryInformation.docx 